\title{
Trend Jual Beli Online Melalui Situs Resmi Menurut Tinjauan Etika Bisnis Islam
}

\author{
Eka Sri Wahyuni \\ IAIN Bengkulu \\ Email : Ekasricurup@gmail.com
}

\begin{abstract}
This paper the trends of buying and selling online through sites in terms of the perspective of Islamic business ethics. This research uses the method of library research (research literature) that is research whose source of information is from various library materials by reading and studying books and writings that have objects with discussion. The results showed that in Indonesia there are various online buying and selling sites, with a very rapid marketplace development in Indonesia. There are many marketplace sites such as Open Stalls, Pedia Stores, OLX, Lazada, Elevenia and others. But the most visited marketplace site today is the Shopee marketplace site. An overview of Islamic business ethics of buying and selling online is permissible as long as the items being traded are in accordance with the appearance of the goods and specifications in the description of the online store. In buying and selling online on the shopee site already meets the applicable requirements in accordance with the appearance and description (specifications of goods) on the storefronts that are extended in the online shop on the shopee site.
\end{abstract}

Kata Kunci : Buy and Sell Online, Islamic Business Ethics, Shopee

Abstrak: Jurnal ini mengkaji trend jual beli online melalui situs di tinjau dari pespektif etika bisnis Islam. Jurnal ini menggunakan metode library research (penelitian kepustakaan) yaitu penelitian yang sumber informasinya dari berbagai bahan kepustakaan dengan cara membaca dan menelaah buku-buku serta tulisan-tulisan yang ada objeknya dengan pembahasan. Hasil penelitian menunjukan bahwa di Indonesia terdapat berbagai situs jual beli online, dengan perkembangan marketplace di Indonesia yang sangat pesat. Ada banyak situs marketplace seperti Buka Lapak, Toko Pedia, OLX, Lazada, Elevenia dan lain-lain. Namun situs marketplace yang paling sering dikunjungi saat ini ialah situs marketplace Shopee. Tinjauan etika bisnis Islam terhadap jual beli online diperbolehkan selama barang yang diperjualbelikan sesuai dengan tampilan barang dan spesifikasi pada deskripsi toko online tersebut. Dalam jual beli online pada situs shopee sudah memenuhi syarat yang berlaku sesuai dengan tampilan dan deskripsi (spesifikasi barang) pada etalase-etalase yang dipanjang di toko online pada situs shopee tersebut.

Kata Kunci : Jual Beli Online, Etika Bisnis Islam, Shopee

PENDAHULUAN

Kegiatan ekonomi tidak lepas

bagaimana kita melakukan aktifitas transaksi guna memenuhi kebutuhan hidup diri sendiri, mensejahterakan keluarga dan membantu orang lain yang membutuhkan 
baik berupa pangan, sandang dan papan. Apabila tidak terpenuhi ketiga alasan ini dapat "dipersalahkan" menurut agama. Konteks ini menganjurkan untuk kita seimbangkan dalam melaksanakan perintah Allah SWT dari sisi ibadah (hablum minallah) dan juga sisi muamalah (hablum minannas).

Dalam mempertahankan hidup seseorang diberi keleluasaan dalam mengambil sikap guna memenuhi kebutuhan-kebutuhanya. Keleluasaan atau kebebasan merupakan fitrah sebagai manusia mengatur dalam memenuhi kebutuhan yang ada. Manusia dapat memaksimalkan dalam memanfatakan sumber daya yang ada bila manusia memiliki kesadaran yang sama maka manusia beramai-ramai usaha apapun yang lebih sistematis efisien dan efektif dalam rangka mengelola sumber daya yang tidak terbatas.

Salah satu fenomena mu'amalah dalam bidang ekonomi adalah transaksi jual beli yang menggunakan media elektronik. Aktivitas perdagangan melalui media internet ini populer disebut dengan electronic commerce atau yang disingkat dengan $e$ commerce. E-commerce (situs jual beli online) merupakan suatu aktivitas perniagaan seperti layaknya perniagaan pada umumnya, hanya saja para pihak yang bertransaksi tidak bertemu secara fisik akan tetapi sacara elektronik melalui media internet. ${ }^{1}$

Sebagaimana dalam konsep perdagangan, situs jual beli online menimbulkan perikatan antara para pihak untuk memberikan suatu prestasi. Implikasi dari perikatan itu adalah timbulnya hak dan kewajiban yang harus dipenuhi oleh para pihak yang terlibat. Lalu bagaimana dengan pandangan Islam tentang hal ini. Jual beli merupakan salah satu jenis mu'amalah yang diatur dalam Islam.

Melihat bentuknya situs jual beli online pada dasarnya merupakan model transaksi jual beli, yang dikategorikan sebagai jual beli modern karena mengimplikasikan inovasi teknologi. Secara umum perdagangan secara Islam menjelaskan adanya transaksi yang bersifat fisik, dengan menghadirkan benda tersebut sewaktu transaksi, sedangkan situs jual beli online tidak seperti itu. Dan permasalahannya juga tidaklah sesederhana itu. situs jual beli online merupakan model perjanjian jual beli dengan karakteristik yang berbeda dengan model transaksi jual beli biasa, apalagi dengan daya jangkau yang tidak hanya lokal tapi juga bersifat global.

Kegiatan situs jual beli online saat ini semakin marak, karena ditambah dengan adanya situs yang digunakan untuk

${ }^{1}$ Gemala Dewi, dkk. Hukum Perikatan Islam Di Indonesia, cet. 2, (Jakarta: Kencana, 2005), h. 196 
melakukan transaksi jual beli online ini semakin baik dan beragam. Hal ini tidak lepas dari perkembangan marketplace di Indonesia yang sangat pesat. Ada banyak situs marketplace seperti Buka Lapak, Toko Pedia, OLX, Lazada, Elevenia dan lain-lain. Namun situs marketplace yang paling sering dikunjungi saat ini ialah situs marketplace Shopee. Situs shopee hadir pada tahun 2015 dan merupakan pusat jual beli online terbesar di Indonesia yang dikunjungi oleh lebih dari 100.000 pengunjung setiap harinya, dengan rata-rata 67.68 juta pengunjung per bulan. Shopee sendiri merupakan situs marketplace termuda dari salah satu situs marketplace di Indonesia. Namun dengan promosi yang gencar e-commerce ini mampu berdiri sejajar dengan pesaing-pesaing terdahulunya tersebut. Shopee memudahkan para penjual serta pembeli dalam berinteraksi melalui fitur live chatnya. Sarana jual beli ini juga menyediakan banyak produk mulai dari gadget, fashion, kosmetik, elektronik, otomotif dan lain sebagainya. $^{2}$

Dalam berbisnis menurut etika bisnis Islam, pada jual beli online penjual dituntut bersikap tidak kontradiksi secara disengaja antara ucapan dan perbuatan dalam bisnisnya. Mereka dituntut tepat janji, tepat waktu, mengakui kelemahan dan

${ }^{2}$ Thidi, Sejarah Shopee Dari Mulai Berdiri Serta Kekurangan dan Kelebihan, Dikutip dari http://thidiweb.com, Diakses pada hari Senin, tanggal 01 Juli 2019, Pukul 08.00 WIB kekurangan, selalu memperbaiki kualitas barang atau jasa secara berkesinambungan serta tidak boleh menipu dan berbohong. Penjual harus memiliki amanah dengan menampilkan sikap keterbukaan, kejujuran, pelayanan yang optimal, dan berbuat baik dengan segala hal, apalagi berhubungan dengan pelayanan masyarakat. Dengan sifat amanah, pelaku usaha memiliki tanggung jawab untuk mengamalkan kewajibankewajibannya. $^{3}$

Dengan berkembangnya zaman yang semakin modern dunia bisnis semakin cenderung mengabaikan etika. Sekalipun mendatangkan banyak perdebatan, gagasan perdagangan bebas dan persaingan bebas terus bergulir sebagai akibat bangkitnya kegairahan organisasi-organisasi bisnis dan perdagangan dunia. Faktanya, persaingan berkembang mengarah pada praktek-praktek persaingan liar yang menghalalkan segala cara. Seperti halnya sebuah permainan dimana ada yang kalah maupun yang menang. Karena dalam bisnis seseorang dituntut untuk berani menanggung resiko. Di dunia bisnis dengan modal yang kecil dapat berharap suatu saat bisnis tersebut menjadi besar dan mendapat laba yang besar. Sehingga para pebisnis berusaha melakukan apa saja agar usahannya berkembang pesat terutama dalam berbisnis jual beli online.

\footnotetext{
${ }^{3}$ Veithzal Rivai, Islamic Business And Economic Ethics (Jakarta: Bumi Aksara, 2012), 237
} 
Seiring dengan pesatnya situs marketplace dalam melakukan transaksi jual beli online, ternyata turut pula menimbulkan berbagai permasalahan. Beberapa permasalahan yang dapat muncul dalam transaksi online ialah (a) kualitas barang yang dijual, hal ini dikarenakan pembeli tidak melihat secara langsung barang yang akan dibeli. Pembeli hanya melihat tampilan gambar dari barang yang dijual, sehingga pembeli belum bisa memastikan secara konkrit apakah barang tersebut sudah sesuai dengan spesifikasi atau kriteria yang ingin dibeli. (b) lamanya estimasi pengiriman pada barang, menimbulkan kekhawatiran pembeli terhadap produk atau barang yang dibeli tersebut. (c) ketika barang tersebut sudah sampai di tangan pembeli, barang yang diterima tidak sesuai dengan barang yang di jual pada situs toko online tersebut, baik itu spesifikasi, jenis, dan sifat barang yang dijual. (d) ketika pembeli mengajukan hak komplain (refund) kepada situs toko online, tidak semua penjual toko online mau merespon terhadap barang yang di komplain.

Salah satu hal yang membedakan bisnis online dengan bisnis off line adalah proses transaksi dan media utama dalam proses tersebut. Proses transaksi merupakan unsur penting dalam suatu bisnis. Secara umum, bisnis dalam Islam menjelaskan adanya transaksi yang bersifat fisik, dengan menghadirkan benda tersebut ketika transaksi, atau tanpa menghadirkan benda yang dipesan, tetapi dengan ketentuan harus dinyatakan sifat benda secara konkret, baik diserahkan langsung atau diserahkan kemudian sampai batas waktu tertentu.

\section{METODE PENELITIAN}

Penelitian ini dilakukan di Kota Bengkulu Provinsi Bengkulu. Jenis penelitian yang digunakan dalam penelitian ini adalah library research (penelitian kepustakaan) yaitu penelitian yang sumber informasinya dari berbagai bahan kepustakaan dengan cara membaca dan menelaah buku-buku serta tulisan-tulisan yang ada objeknya dengan pembahasan. Penelitian ini menggunakan pendekatan deskriptif kualitatif, data fakta yang dihimpun berbentuk kata atau gambar dari pada angka-angka (tidak diperoleh melalui prosedur statistik atau bentuk hitung lainnya). ${ }^{4}$

Dalam menganalisis data peneliti mengumpulkan data-data, setelah data-data terkumpul, selanjutnya data-data tersebut dianalisa dengan teknik analisis isi (konten analisis) yaitu menelaah dengan kosa kata, pola kalimat, situasi, dan latar belakang budaya dalam penulisan tentang jual beli online.

${ }^{4}$ Djam'an Satori dan Aan Komariah, Metodologi Penelitian Kualitatif, (Bandung: Alfabeta, 2017), h. 28 


\section{HASIL PENELITIAN}

\section{PEMBAHASAN}

\section{Jual Beli}

Muamalah dalam Islam mempunyai posisi dan peran sangat signifikan, karena merupakan bagian penting dari hidup dan kehidupan manusia. Muamalah sangat menentukan keberlangsungan hidup manusia dan kehidupan masyarakat. Jual beli sebagai bagian dari muamalah mempunyai dasar hukum yang jelas. Baik dari Al-Quran, AlSunnah dan telah menjadi ijma' ulama dan kaum muslimin. Bahkan jual beli bukan hanya sekedar muamalah, akan tetapi menjadi salah satu media untuk melakukan kegiatan untuk saling tolong-menolong sesama manusia. ${ }^{5}$ menurut etimologi atau bahasa, jual beli adalah pertukaran harta atas dasar saling merelakan atau memindahkan hak milik dengan ganti yang dapat dibenarkan. ${ }^{6}$ Adapun jual beli menurut terminologi, para ulama berbeda pendapat dalam mendefinisikannya, antara lain :

a. Menurut ulama Asy-Syafi'i: jual beli adalah pertukaran barang dengan barang lainnya. $^{7}$

${ }^{5}$ Imam Mustofa, Fiqih Mu'amalah Kontemporer, (Jakarta: PT, Raja Grafindo Persada, 2016), h.22

${ }^{6}$ Mustafa Kamal Pasha, dkk. Fikih Islam, (Jogjakarta: Surya Mediatama, 2017), h.371

${ }^{7}$ Muhammad Rizki Romdhon, Jual Beli Online Menurut Madzhab Asy-Syafi'i, (Tasikmalaya: Pustaka Cipasung, 2015), h.67 b. Menurut ulama Maliki: jual beli adalah untuk seluruh satuannya bai' (jual beli), yang mencakup akad sharaf, salam dan lain sebagainya.

c. Menurut ulama Hambali: jual beli adalah Saling menukar harta dengan harta dalam bentuk pemindahan milik dan pemilikan.

d. Menurut ulama Hanafi: jual beli adalah pertukaran harta (benda) dengan harta berdasarkan cara khusus (yang dibolehkan).

e. Menurut imam Nawawi dalam $A l$ Мајти': jual beli adalah pertukaran harta dengan harta untuk kepemilikan.

f. Menurut Ibnu Qudamah dalam kitab mugni: jual beli adalah pertukaran harta dengan harta untuk saling menjadikan milik. $^{8}$

Secara terminologi, jual beli diartikan dengan "tukar-menukar harta secara suka sama suka" kata tukar-menukar atau peralihan pemilikan dengan penggantian mengandung maksud yang sama, bahwa kegiatan mengalihkan hak dan pemilikan itu berlangsung secara timbal balik atas dasar kehendak dan keinginan bersama. ${ }^{9}$

Berdasarkan pemaparan berbagai definisi di atas, maka dapat diambil kesimpulan bahwa yang dimaksud dengan jual beli ialah pertukaran harta atas dasar

\footnotetext{
8 Rachmad Syafe'I, Fiqh Muamalah, (Bandung: Pustaka Setia, 2000), h.73

${ }^{9}$ Amir Syarifuddin, Garis-Garis Besar Fiqh, (Jakarta: Kencana, 2010), h.193
} 
saling merelakan, atau memindahkan hak milik dengan ganti yang dapat dibenarkan. Objek jual beli berupa barang yang diperjualbelikan dan uang pengganti barang tersebut. Suka sama suka merupakan kunci dari transaksi jual beli. Karena tanpa adanya kesukarelaan dari masing-masing pihak atau salah satu pihak. Maka jual beli tidak sah.

\section{Dasar Hukum Jual Beli}

Firman Allah SWT dalam surah AnNisa ayat 29 :

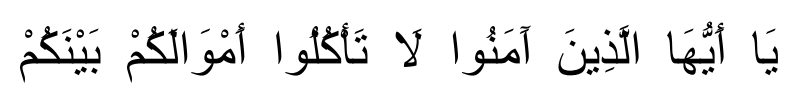

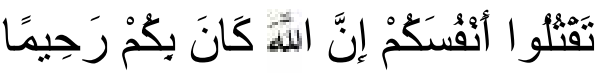

Artinya: Wahai orang-orang yang beriman, janagnlah kalian memakan harta-harta kalian di antara kalian dengan cara yang batil, kecuali dengan perdagangan yang kalian saling ridha. Dan janganlah kalian membunuh diri-diri kalian, sesungguhnya Allah itu Maha Kasih Sayang kepada kalian. (Q.S An-Nisa'-29).

Jelas bahwa dasar perniagaan adalah meridhai antara pembeli dan penjual. Penipuan, dan pendustaan serta pemalsuan adalah hal-hal yang diharamkan. Jadi ayat tersebut memberikan penjelasan bahwa jual beli atau perniagaan tidak dapat dilepaskan dari unsur keridhaan atau saling suka dan rela antara pihak penjual dan pembeli. Dalam konteks maqashid, prinsip dalam perdagangan harus dilakukan atas dasar suka sama suka (kerelaan). Prinsip ini memiliki implikasi yang luas karena perdagangan melibatkan lebih dari satu pihak, sehingga kegiatan jual beli harus dilakukan secara sukarela, tanpa paksaan. ${ }^{10}$ Hal ini menunjukan bahwa jual beli yang tidak diiringi dengan kerelaan dilarang Allah Swt.

Sementara landasan dari Al-Sunnah antara lain diriwayatkan Rifa'ah bin Rafi' alBazar dan Hakim:

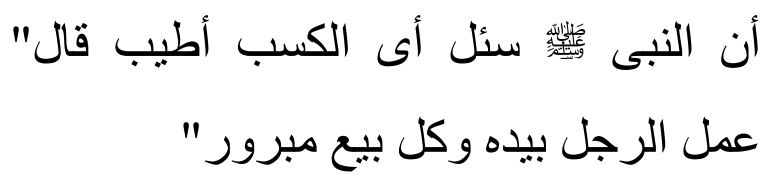

"Rasulullah SAW. Bersabda ketika ditanya tentang mata pecaharian yang paling baik. Beliau menjawab, 'seseorang bekerja dengan tangannya dan setiap jual beli yang mabrur." (HR. Bajjar, Hakim menshahihkannya dari Rifa'ah Ibn Rafi')

Berdasarkan hadist tersebut jelas disebutkan bahwa usaha yang baik hasilnya adalah jual beli (berbisnis) karena dengan berbisnis manusia dapat memenu hi kebutuhannya. Berbisnis yang dimaksud adalah berbisnis yang jujur, tidak menipu atau berbohong. Dimana diketahui bersama bahwa Rasulullah SAW adalah pedagang yang jujur.

Ulama telah sepakat bahwa jual beli diperbolehkan dengan alasan bahwa manusia tidak akan mampu untuk mencukupi kebutuhan dirinya, tanpa bantuan orang lain. Namun demikian, bantuan atau barang milik

${ }^{10}$ Oni Sahroni dan Adiwarman A. Karim, Maqashid Bisnis dan Keuangan Islam: Sintesis Fikih dan Ekonomi, cet 2, (Jakarta: Rajawali Pers, 2016), h. 67 
orang lain yang dibutuhkannya itu, harus diganti dengan barang lainnya yang sesuai.

\section{Rukun Dan Syarat Jual Beli}

Dalam menetapkan rukun jual beli, diantara para ulama terjadi perbedaan pandapat. Menurut ulama Hanafiah, rukun jual beli adalah ijab dan qabul yang menunjukan pertukaran barang secara ridha, baik dengan ucapan maupun perbuatan. Adapun rukun jual beli menurut jumhur ulama ada empat, yaitu ${ }^{11}$ :

a. Penjual (bai')

Penjual adalah pihak yang memiliki objek barang yang akan diperjual belikan.

b. Pembeli (mustari)

Pembeli adalah pihak yang ingin memperoleh barang yang akan diharapkan, dengan membayar sejumlah uang tertentu kepada penjual.

c. Ijab dan qabul (shigat)

Ijab dari segi bahasa berarti "pewajiban atau perkenaan", sedangkan qabul bearti “penerimaan”. Dalam jual beli ucapan atau tindakan yang lahir pertama kali dari salah satu yang berakad disebut ijab, kemudian ucapan atau tindakan yang lahir sesudahnya disebut qabul.

d. Benda atau barang (ma'qud 'alaih), sebagai berikut:

\footnotetext{
${ }^{11}$ Rahmad Syafe'I, Fiqh Muamalah, ... h. 74-
}

1. Bahwa di dalam ajaran Islam dilarang melakukan jual beli barang-barang yang mengandung unsur najis ataupun barang-barang yang dinyatakan diharamkan.

2. Barang yang diperjual belikan adalah sesuatu yang bermanfaat, alasannya bahwa yang hendak diperoleh dari transaksi ini adalah manfaat itu sendiri. Bila barang tersebut tidak ada manfaatnya bahkan dapat merusak seperti ular dan kalajengking, maka tidak dapat dijadikan objek transaksi.

3. Baik barang atau uang yang dijadikan objek transaksi itu betul-betul telah menjadi milik orang yang akan melakukan transaksi. Hal ini mengandung unsur tidak boleh menjual barang orang lain, kecuali ada izin atau kuasa dari orang yang memilikinya.

4. Barang atau yang yang telah menjadi miliknya itu haruslah telah berada ditangannya atau dalam kekuasaanya dan dapat diserahkan sewaktu transaksi, dan tidak mesti berada dalam majelis akad, umpamanya tersimpan dalam gudang penyimpanan yang berjauhan letaknya.

5. Barang atau uang dijadikan objek transaksi itu mestinya sesuatu yang diketahui secara transaparan, baik kuantitas maupun jumlahnya, baik 
timbang jelas timbangannya dan bila sesuatu takaran jelas takarnya. ${ }^{12}$

Dalam jual beli terdapat empat syarat, yaitu syarat terjadinya akad, syarat sahnya akad, syarat terlaksananya, dan syarat lujum. Secara umum tujuan adanya semua syarat tersebut antara lain untuk menghindari pertentangan diantara manusia, menjaga kemaslahatan orang yang sedang akad, menghindari jual beli gharar (terdapat unsur penipuan) dan lain-lain. Jika jual beli tidak memenuhi syarat terjadinya akad, akad tersebut batal. Jika tidak memenuhi syarat sah, menurut ulama hanafiyah akad tersebut fasid. Jika tidak memenuhi syarat nafadz, akad tersebut mauquf yang cenderung boleh, bahkan menurut ulama malikiyah cenderung kepada kebolehan. Jika tidak memenuhi syarat lajum, akad tersebut mukhayyir (pilihpilih), baik khiyar untuk menetapkan maupun membatalkan.

\section{Jual Beli Online}

E-commerce (jual beli online) merupakan salah satu implementasi dari bisnis online. Berbicara mengenai bisnis online tidak terlepas dari transaksi-transaksi, seperti jual beli internet. Transaksi inilah yang kemudian dikenal dengan electronic commerce yang lebih populer dengan istilah e-commerce dan saat ini dalam pengertian bahasa Indonesia telah dikenal dengan istilah

\footnotetext{
${ }^{12}$ Rahmad Syafe'I, Fiqh Muamalah, ... h. 76
}

"Perniagaan Elektronik". 13 E-commerce merupakan aktifitas pembelian, penjualan, pemasaran, dan pelayanan atas produk dan jasa yang ditawarkan melalui jaringan komputer. Dunia industri teknologi informasi melihatnya sebuah aplikasi bisnis secara electronic yang mengacu pada transaksitransaksi komersial. ${ }^{14}$

Jual beli online adalah persetujuan saling mengikat melalui internet antara penjual sebagai pihak yang menjual barang dan pembeli sebagai pihak yang membayar harga barang yang dijual. Jual beli secara online menerapkan sistem jual beli di internet. Tidak ada kontak secara langsung antara penjual dan pembeli. Jual beli online dilakukan melalui suatu jaringan yang terkoneksi dengan menggunakan handphone, komputer, tablet, dan lain-lain.

Dalam e-commerce seorang penjual memberikan penawaran terhadap barang yang dimilikinya untuk dijual melalui media elektronik, yaitu internet dengan memasukan penawaran tersebut dalam situs, baik yang ia kelola sendiri untuk melakukan perdagangan atau memasukkannya dalam situs lain. Pembeli di sini dapat dengan leluasa memilih transaksi mana yang sesuai dengan yang ia cari. Dalam menjelajah situs dalam internet, pembeli layaknya orang yang berbelanja

\footnotetext{
${ }^{13}$ Gemala Dewi, dkk. Hukum Perikatan Islam Di Indonesia, cet. 2, (Jakarta: Kencana, 2005), h. 195.

${ }^{14}$ Imam Mustofa, Fiqih Mu'amalah Kontemporer, ... h. 32
} 
secara konvensional dengan melihat etalaseetalase yang dipajang oleh tiap-tiap toko dan jika ia menemukan sesuatu yang ia cari maka ia dapat melakukan transaksi dengan penjual yang memberikan penawaran dalam situs tersebut yang diandaikan dengan toko secara konvensional. ${ }^{15}$

Adapun yang menjadi objek jual beli online, yaitu barang yang dibeli oleh konsumen, namun barang tidak dilihat langsung oleh pembeli. Hal ini berbeda dengan jual beli pada umumnya, yakni penjual dan pembeli dapat bertemu dan melihat objek jual beli secara langsung, sehingga memungkinkan pembeli mendapatkan kepastian mengenai kualitas barang yang ingin dibelinya, sehingga kemungkinan dapat menghindari adanya penipuan.

Sementara mengenai syarat adanya barang dan uang sebagai pengganti harga barang, maka dalam transaksi jual beli via elektronik atau e-commerce tidak dilakukan secara langsung dalam dunia nyata. Dalam hal bentuk dan wujud barang yang menjadi objek transaksi, dalam e-commerce biasanya hanya berupa gambar (foto atau video) yang menunjukan barang aslinya kemudian dijelaskan spesifikasi sifat dan jenisnya. Pembeli dapat dengan bebas memilih barang sesuai dengan spesifikasi yang diinginkan.

\footnotetext{
${ }^{15}$ Gemala Dewi, dkk. Hukum Perikatan Islam Di Indonesia, ... h. 196-197
}

Barang akan dikirim setelah uang dibayar. Mengenai sistem pembayaran atau penyerahan uang pengganti barang, maka umumnya adalah dilakukan dengan cara transfer. ${ }^{16}$

\section{Macam-Macam Jual Beli Online}

Di Indonesia sendiri ada beberapa jenis teransaksi jual beli online yang biasa dilakukan oleh konsumen jual beli online, yaitu: ${ }^{17}$

\section{a. Cash On Delivery (COD)}

1. Membayar ke penjual langsung

Penjual dan pembeli menentukan tempat yang dispakati untuk bertransaksi sehingga pembeli dapat memeriksa kondisi produk apakah sesuai yang digambarkan oleh penjual, dan penjual dapat menerima pembayaran secara langsung.

2. Membayar melalui jasa kurir (Delivery Service)

Penjual dan pembeli sepakat untuk menggunakan jasa kurir/delivery Service untuk mengirimkan produk dari penjual dan pembeli membayar uang pembelian barang melalui jasa kurir/delivery service.

b. Debit On Delivery atau Credit On Delivery

\footnotetext{
${ }^{16}$ Imam Mustafa, Fiqih Mu'amalah Kontemporer ,...h. 45

${ }^{17}$ Muhammad Rizki Romdhon, Jual Beli Online Menurut Madzhab Asy-Syafi'i, ...h. 96-99
} 
Selain COD, adapula transaksi dengan cara Debit On Delivery yaitu pembeli bertransaksi dengan menggunakan kartu debit yang dikeluarkan bank, pembeli dapat menggesek secara tunai kepada agen pengiriman setelah menerima pesanan. Atau bisa pula menggunakan kartu kredit yang dikeluarkan oleh bank dengan cara transaksi seperti Debit On Delivery.

c. Menggunakan Transfer Rekening Bank

Pembayaran atas pembelian barang dibayarkan dengan cara transfer uang tunai antar bank. Pembeli melakukan transfer uang tunai melalui bank dan juga melalui ATM. Atau pembeli melakukan transfer antar bank menggunakan metode internet banking yaitu cara transfer ke rekening bank melalui internet.

d. Menggunakan Dompet Virtual

Dompet Virtual adalah tempat penyimpanan uang di dunia maya, cara kerjanya sama seperti kartu debit. Selain itu juga dompet virtual dapat digunakan pengguna guna menyimpan dana hasil penjualan (remit) dan dana hasil pengembalian (refund) transaksi. Dompet virtual ini bermacam-macam jenisnya seperti Paypal, Kaspay dan lain-lain.

\section{e. Menggunakan Escrow Account}

Escrow Account atau Escrow Service adalah sebuah metode pembayaran untuk penjual maupun pembeli melalui pihak ketiga, dimana pembeli akan mentransferkan uang ke rekening agen elektronik, dan agen elektronik mentransferkan uang ke penjual. Istilah ini dikenal juga dengan nama rekening bersama atau rekber. Rekber adalah suatu instansi yang berperan sebagai perantara dalam terjadinya transaksi online.

Mekanisme rekber adalah pembeli dan penjual sepakat memilih rekber tertentu dan siapa yang akan membayar fee rekber, lalu pembeli mentransferkan yang ke rekber. Setelah itu rekber memberikan notifikasi kepada penjual bahwa pembeli telah mentransferkan uangnya. Lalu penjual mengirimkan barangnya melalui jasa kurir. Setelah barang sampai ditujuan, pembeli menginformasikan kepada rekber bahwa barang telah sampai. Terakhir rekber mentransferkan uang pembayaran pembeli kepada penjual.

\section{Etika Bisnis Islam}

Etika bisnis Islam merupakan suatu proses dan upaya untuk mengetahui hal-hal yang benar dan yang salah, yang selanjutnya tentu melakukan hal yang benar berkenaan dengan produk, pelayanan perusahaan dengan pihak yang berkepentingan dengan tuntutan perusahaan. ${ }^{18}$

\footnotetext{
${ }^{18}$ Abdul Aziz, Etika Bisnis Prespektif Islam, h.
} 
Berdasarkan pemaparan definisi di atas, maka dapat diambil kesimpulan bahwa yang dimaksud dengan etika bisnis Islam ialah seperangkat prinsip dan norma di mana para pelaku bisnis harus komit padanya dalam berinteraksi, berperilaku, dan berelasi guna mencapai tujuan-tujuan bisnisnya dengan selamat.

\section{Dasar Hukum Etika Bisnis Islam}

Al-Qur'an dalam mengajak manusia untuk mempercayai dan Mengamalkan tuntutan-tuntutannya untuk segala aspek kehidupan. Seringkali menggunakan istilahistilah yang dikenal dalam dunia bisnis, seperti jual beli, untung-rugi, dan sebagainya. Dalam konteks ini Al-Qur'an menjanjikan :

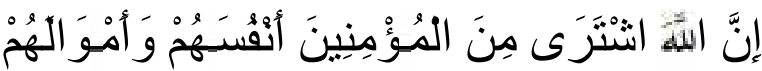

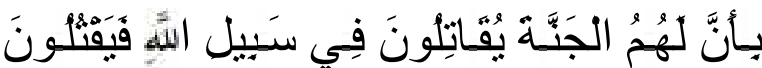

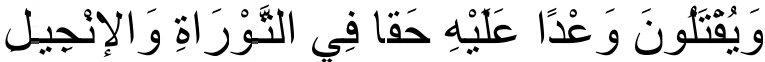

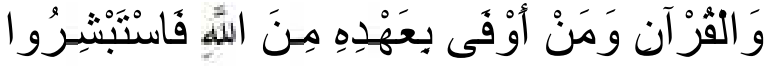

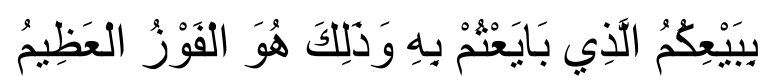

Artinya : "Sesungguhnya Allah telah membeli dari orang-orang mukmin diri dan harta mereka dengan memberikan surga untuk mereka. mereka berperang pada jalan Allah; lalu mereka membunuh atau terbunuh. (itu telah menjadi) janji yang benar dari Allah di dalam taurat, injil dan al-Quran. dan siapakah yang lebih menepati janjinya (selain) daripada Allah? Maka bergembiralah dengan jual beli yang telah kamu lakukan itu, dan itulah kemenangan yang besar”. (QS. At-Taubah: 111).
Pada ayat tersebut, mereka yang tidak ingin melakukan aktivitas kehidupannya kecuali bila memperoleh keuntungan semata, dilayani (ditantang) oleh Al-Qur'an dengan menawarkan satu bursa yang tidak mengenal kerugian dan penipuan. ${ }^{19}$

\section{Prinsip-Prinsip Etika Bisnis Islam}

Untuk memperoleh keberkahan, seorang pelaku bisnis harus memperhatikan beberapa prinsip-prinsip etika bisnis yang telah digariskan dalam Islam, antara lain: ${ }^{20}$

a. Kesatuan (Tauhid)

Kesatuan ini dimaksudkan bahwa sumber utama etika bisnis Islam adalah kepercayaan total dan murni terhadap kesatuan (keesaan) Allah SWT. Berdasarkan prinsip kesatuan ini, maka pengusaha muslim dalam melakukan entitas bisnisnya tidak akan melakukan paling tidak tiga hal: Pertama, diskriminasi diantara pekerja, penjual, pembeli, pemasok, mitra kerja atas dasar pertimbangan ras, jenis kelamin atau agama. Kedua, terpaksa atau dipaksa untuk melakukan praktik-praktik mal bisnis karena ia hanya takut dan cinta kepada Allah SWT. Ketiga, menimbun kekayaannya dengan penuh keserakahan karena konsep amanah sangat penting

\footnotetext{
${ }^{19}$ Muhammad, Alimin, Etika \& Perlindungan Konsumen Dalam Ekonomi Islam (Yogyakarta: BPFE-Yogyakarta, 2004), h. 56.

${ }^{20}$ Muhammad Djakfar, Etika Bisnis Dalam Perspektif Islam, (Malang: UIN Malang Press, 2007), h. 21.
} 
bagi seorang muslim dan semua harta hanya bersifat sementara maka harus dengan bijaksana. ${ }^{21}$

b. Keseimbangan

Dalam beraktivitas di dunia kerja dan bisnis, Islam mengharuskan untuk berbuat adil, tak terkecuali pada pihak yang tidak disukai. Pada dataran ekonomi, konsep keseimbangan menentukan konfigurasi aktivitas-aktivitas distribusi, konsumsi serta produksi yang terbaik, dengan pemahaman yang jelas bahwa kebutuhan seluruh anggota masyarakat yang kurang beruntung dalam masyarakat Islam di dahulukan atas sumber daya riil masyarakat. Tidak terciptanya keseimbangan sama halnya dengan terjadinya kedhaliman.

Dengan demikian, Islam menuntut keseimbangan antara kepentingan diri dan kepentingan orang lain, antara kepentingan si kaya dan si miskin, antara hak pembeli dan hak penjual dan lain sebagainya. $^{22}$

Penerapan konsep keseimbangan ini sebagai contoh adalah Allah SWT memperingatkan para pengusaha muslim untuk menyempurnakan takaran timbangan dalam jual beli. Sangat menarik untuk mengetahui makna adl

\footnotetext{
${ }^{21}$ Rafik Isa Beekum, Etika Bisnis Islam, (Yogyakarta: Pustaka Pelajar, 2004), h. 35.

${ }^{22}$ Muhammad Djakfar, Etika Bisnis Dalam Prespektif Islam, h. 15.
}

adalah keadilan atau kesetaraan. Secara keseluruhan Islam ingin mengekang kecenderungan sikap serakah manusia dan kecintaanya untuk memiliki barangbarang. $^{23}$

c. Kehendak Bebas

Kebebasan merupakan bagian Penting dalam nilai etika bisnis Islam, tetapi kebebasan itu tidak merugikan kepentingan kolektif. Dalam pandangan Islam, manusia dianugerahi potensi untuk berkehendak dan memilih di antara pilihan-pilihan yang beragam, kendati kebebasan yang dimiliki Allah. ${ }^{24}$ Kebebasan merupakan bagian Penting dalam nilai etika bisnis Islam.

Penerapan konsep kehendak bebas dalam etika bisnis Islam ialah manusia memiliki kebebasan untuk membuat kontrak dan menepatinya ataupun mengingkarinya. Seorang muslim yang telah menyerah hidupnya pada kehendak Allah SWT akan menepati semua kontrak yang telah ia buat. ${ }^{25}$

d. Tanggung Jawab

Penerapan konsep tanggung jawab dalam etika bisnis Islam misalnya jika seorang pengusaha muslim berperilaku secara tidak etis, ia tidak dapat menyalahkan tindakannya pada

\footnotetext{
${ }^{23}$ Rafik Isa Beekun, Etika Bisnis Islam, h. 37.

${ }^{24}$ Muhammad Djakfar, Etika Bisnis Dalam Prespektif Islam, h. 16.

${ }^{25}$ Rafik Isa Beekun, Etika Bisnis Islam, h. 39.
} 
persoalan tekanan bisnis ataupun pada kenyataan bahwa setiap orang juga berperilaku tidak etis. Ia harus memikul tanggung jawab tertinggi atas tindakannya sendiri. $^{26}$

e. Kebenaran (Kejujuran dan Kebajikan)

Dalam konteks bisnis kebenaran dimaksudkan sebagai niat, sikap dan perilaku benar yang meliputi proses akad (transaksi) proses mencari atau memperoleh komoditas pengembangan maupun dalam proses upaya meraih atau menetapkan keuntungan. Dengan prinsip kebenaran ini maka etika bisnis Islam sangat menjaga dan berlaku preventif terhadap kemungkinan adanya kerugian salah satu pihak yang melakukan transaksi, kerja sama atau perjanjian dalam bisnis.

Semakin berkembangannya teknologi telah memacu perubahan kebiasaan individu termasuk salah satunya dalam hal kebiasaan melakukan kegiatan jual beli. Apabila dahulu yang dimaksudkan jual beli harus dilakukan secara tatap muka di mana terjadi peralihan barang secara langsung dari penjual kepada pembeli, yaitu pembeli harus bertemu dengan penjual di pasar nyata. Saat ini telah beralih kepada era di mana jual beli tidak lagi dilakukan secara tatap muka, melainkan sudah melalui trend media online . Tidak lagi

\footnotetext{
${ }^{26}$ Rafik Isa Beekun, Etika Bisnis Islam, h. 42.
}

harus terjadi pertemuan antara penjual dengan pembeli di pasar, melainkan cukup dengan menggunakan teknologi internet dan langsung terjadi transaksi antara penjual dan pembeli. Telah terdapat berbagai macam produk yang dijual tidak lagi melakukan penjualan secara tatap muka semata, melainkan sudah meng gunakan teknologi untuk melakukan penjualan secara online.

Transaksi online atau lebih dikenal dengan e-commerce (jual beli online) merupakan aktifitas pembelian, penjualan, pemasaran, dan pelayanan atas produk dan jasa yang ditawarkan melalui jaringan komputer. ${ }^{27}$ Jual beli online dapat diartikan juga suatu kegiatan ataupun aktivitas jual beli berupa transaksi penawaran barang, dimana penjual dan pembelinya tidak harus bertemu langsung untuk melakukan penawaran dan pembelian terhadap suatu barang secara online dengan memanfaatkan teknologi internet.

Etika bisnis Islam merupakan suatu kebiasaan atau budaya moral yang berkaitan dengan kegiatan bisnis suatu perusahaan. Sedangkan etika bisnis Islam adalah studi tentang seseorang atau organisasi dalam melakukan usaha atau kontrak bisnis yang saling menguntungkan sesuai dengan nilainilai ajaran Islam. Adapun analisis jual beli

${ }^{27}$ Imam Mustofa, Fiqih Mu'amalah Kontemporer, (Jakarta: PT, Raja Grafindo Persada, 2016), h. 32 
online melalui situs resmi ditinjau menurut prinsip-prinsip etika bisnis Islam, antara lain:

\section{Prinsip Kesatuan (Tauhid)}

Dalam menjalankan bisnis, seseorang harus mempunyai prinsip kesatuan, hal ini dengan tujuan untuk mengontrol pikiran, sikap, tindakan, dan perilaku individu dalam menjalankan roda ekonomi dan bisnisnya. Berdasarkan analisis, dalam proses jual beli online pembeli tidak melihat secara langsung barang yang akan dibeli. Pembeli hanya melihat tampilan gambar dari barang yang dijual, sehingga pembeli belum bisa memastikan secara konkrit terhadap barang yang ingin dibeli. Pada situs shopee sendiri hanya menampilkan gambar dan deskripsi penjelasan untuk setiap produknya, namun pembeli bisa melihat penilaian yang diberikan kepada pihak shopee, berupa saran, kesan, bahkan komplain tentang pelayanan shopee pada toko online tersebut. Review ini bisa berpengaruh pada pembeli terhadap barang yang ingin dibeli. Karena saran, kesan, juga komplain dapat menjadi pertimbangan jadi tidaknya proses transaksi di toko online pada situs shopee. Dan di kolom komentar banyak sekali komentar-komentar dari para pembeli tentang pelayanan di toko online pada situs shopee tersebut. Jika ditinjau etika bisnis Islam jual beli online diperbolehkan selama barang yang diperjualbelikan sesuai dengan tampilan barang dan spesifikasi pada deskripsi toko online tersebut. Artinya jual beli online pada situs shopee boleh dilakukan, dengan catatan harus sesuai dengan tampilan dan deskripsi (spesifikasi barang) pada etalase-etalase yang dipanjang di toko online pada situs shopee tersebut, serta tidak menyimpang dari prilaku penipuan sesuai dengan prinsip etika bisnis Islam.

\section{Prinsip Keseimbangan}

Islam menuntut keseimbangan antara kepentingan diri dan kepentingan orang lain, antara hak pembeli dan hak penjual dan lain sebagainya. keseimbangan dibentuk dengan pendekatan kontrak, dimana asas-asas keseimbangan dipilih berdasarkan kesepakatan bersama dari semua pihak, Tanpa merugikan salah satu pihak. Berdasarkan analisis, dalam proses jual beli online, setiap transaksi haruslah sesuai dengan kesepakatan/kontrak, tanpa adanya kesepakatan maka jual beli online tersebut tidak sah. Pada situs shopee sendiri kesepakatan/kontrak dalam transaksi sangat penting, dikarenakan kesepakatan merupakan modal utama bagi pihak shopee dalam keberlangsungan bisnis. Jika ditinjau etika bisnis Islam, prinsip kkeseimbangan atau keadilan merupakan prioritas utama dalam 
melakukan aktifitas perniagaan

dikarenakan Islam mengharuskan umatnya untuk berbuat adil tanpa terkecuali. Artinya dalam jual beli online tersebut semua pihak yang terlibat dalam transaksi wajib berlaku adil dalam melakukan kegiatan bisnis sesuai dengan prinsip etika bisnis Islam.

\section{Prinsip Kehendak Bebas}

Kebebasan merupakan bagian Penting dalam nilai etika bisnis Islam, tetapi kebebasan itu tidak merugikan kepentingan kolektif. Berdasarkan analisis, dalam proses jual beli online, lamanya estimasi pengiriman pada barang, menimbulkan kekhawatiran pembeli terhadap produk atau barang yang dibeli pada situs jual beli online tersebut, dan langsung menyalahkan toko online selaku pihak pengirim paket. Pada situs shopee sendiri adanya keterlambatan pada barang sebenarnya bukanlah kesalahan dari pihak toko online pada situs jual beli tersebut, akan tetapi kesalahan/kelalaian dari pihak jasa pengiriman barang yang menyebabkan terjadinya keterlambatan pengiriman barang kepada pembeli. Jika ditinjau etika bisnis Islam, kebebasan merupakan bagian Penting dalam nilai etika bisnis Islam, tetapi kebebasan itu tidak merugikan kepentingan kolektif. Manusia memiliki kebebasan untuk membuat kontrak dan menepatinya. Dalam jual beli online tersebut pihak yang bertransaksi harus menepati semua kontrak yang telah ia buat. Apabila terjadi keterlambatan maka pihak yang terikat/terlibat harus segera mengkonfirmasi agar tidak terjadinya kesalahpahaman dalam bertransaksi.

4. Prinsip Tanggung Jawab

$\begin{array}{cll}\text { Manusia } & \text { harus } & \text { berani } \\ \text { mempertanggung } & \text { jawabkan } & \text { segala }\end{array}$
pilihannya tidak saja dihadapan manusia, bahkan yang paling penting adalah kelak di hadapan Allah SWT. Bisa saja, karena kelihaiannya, manusia mampu melepaskan tanggung jawab perbuatannya yang merugikan manusia, namun kelak ia tidak akan pernah lepas dari tanggung jawab di hadapan Allah Yang Maha Mengetahui. Berdasarkan analisis, dalam proses jual beli online, ketika barang tersebut sudah sampai di tangan pembeli, barang yang diterima tidak sesuai dengan barang yang di jual pada situs toko online tersebut, baik itu spesifikasi, jenis, dan sifat barang yang dijual, dan ketika pembeli mengajukan hak komplain (refund) kepada situs toko online, tidak semua penjual toko online mau merespon terhadap barang yang di komplain. Pada situs shopee sendiri tidak semua reseller/penjual berlaku jujur dalam jual beli online, ada beberapa penjual yang 
tidak jujur sehingga merugikan pembeli. Dan ada juga penjual yang salah mengirimkan barangnya kepada pembeli. Namun ketika pembeli mengajukan hak komplain (refund) kepada situs toko online tersebut, tidak semua reseller/penjual toko online mau merespon terhadap barang yang di komplain, dan ada juga yang menolak hak komplain terhadap pelanggan tersebut. Sedangkan pada sistem shopee sendiri diperbolehkannya hak pengembalian pada barang (refund) apabila barang yang bersangkutan tidak sesuai dengan deskripsi (spesifikasi) yang ada pada toko online tersebut (reseller bersangkutan). Jika ditinjau etika bisnis Islam, manusia harus berani mempertanggung jawabkan segala pilihannya tidak saja di hadapan manusia, bahkan yang paling penting adalah kelak di hadapan Allah SWT. Dalam perniagaan prinsip tanggung jawab sangatlah penting, prinsip ini merupakan modal utama bagi pelaku bisnis manakala diinginkan bisnisnya mendapat kepercayaan dari konsumen dan masyarakat luas. Dalam jual beli online tersebut pihak yang terikat/terlibat haruslah bersikap tanggung jawab khususnya bagi para pelaku bisnis, boleh mengambil keuntungan dalam jual beli namun hak pembeli harus tetap dihormati.
5. Prinsip Kebenaran (Kejujuran dan Kebajikan)

Dalam konteks bisnis kebenaran dimaksudkan sebagai niat, sikap dan perilaku benar yang meliputi proses akad (transaksi) proses mencari atau memperoleh komoditas pengembangan maupun dalam proses upaya meraih atau menetapkan keuntungan. Dengan prinsip kebenaran ini maka etika bisnis Islam sangat menjaga dan berlaku preventif terhadap kemungkinan adanya kerugian salah satu pihak yang melakukan transaksi, kerja sama atau perjanjian dalam bisnis. Berdasarkan analisis, dalam jual beli online, kebenaran/kejujuran dalam transaksi merupakan unsur yang sangat penting dan salah satu syarat utama dalam jual beli di Indonesia. Pada situs shopee sendiri, dalam menampilkan barang dan deskripsi diwajibkan untuk para reseller/penjual untuk menjual sesuai dengan tampilan dan deskripsi dengan barang yang dijual, dengan tujuan untuk membangun kepercayaan masyarakat dan kepuasan masyarakat terhadap pelayanan situs shopee sendiri. Jika ditinjau etika bisnis Islam, prinsip kebenaran berlaku dalam segala bentuk muamalah, etika bisnis Islam sangat menjaga dan berlaku preventif terhadap kemungkinan adanya kerugian salah satu pihak yang melakukan transaksi. Dalam jual beli online tersebut, 
semua pihak dituntut untuk berprilaku kebenaran dalam bertransaksi, pada situs shopee sendiri sudah sesuai dengan aturan yang berlaku namun masih terdapat beberapa reseller/penjual yang berprilaku curang dengan mengirimkan barang yang tidak sesuai dengan spesifikasi. Ketika pihak pelanggan mengajukan pengembalian pada barang (refund), tidak semua reseller/penjual mau menerima refund pelanggan. Sehingga kebanyakan masyarakat hanya bisa menerima dan memberi tanda "bintang" serta kolom komentar atas ketidakpuasan pelanggan terhadap reseller/penjual pada toko online tersebut.

\section{KESIMPULAN}

Ada banyak marketplace yang ada di Indonesia. Namun situs marketplace yang paling sering dikunjungi saat ini ialah situs marketplace shopee. merupakan pusat jual beli online terbesar di Indonesia yang dikunjungi oleh lebih dari 100.000 pengunjung dengan peningkatan nilai transaksi yang signifikan terutama terhadap momen-momen besar di Indonesia.

Tinjauan etika bisnis Islam terhadap jual beli online pada situs resmi shoope dalam jual beli online tersebut, pihak yang bertransaksi harus menepati semua kontrak yang telah ia buat. Dan harus bersikap tanggung jawab khususnya bagi para pelaku bisnis, boleh mengambil keuntungan dalam jual beli namun hak pembeli harus tetap dihormati.

\section{DAFTAR PUSTAKA}

Arijanto, Agus. Etika Bisnis Bagi Pelaku Bisnis. Jakarta: Rajawali Press. 2011.

Aziz Muhammad Azzam, Abdul. Fiqh Muamalat. Jakarta: Amzah. 2017.

Aziz, Abdul. Etika Bisnis Prespektif Islam. Bandung: Alfabeta. 2013.

Beekum, Rafik Isa. Etika Bisnis Islam. Yogyakarta: Pustaka Pelajar. 2004.

Damayanti, Astri. Strategi Iklan Online (Studi Iklan Shopee Di Media Sosial), Dikutip dari http://etheses.iainponorogo.ac.id, Diakses pada hari Rabu, tanggal 03 Juli 2019, Pukul 17.00 WIB.

Dewi, Gemala., Wirdyaningsih dan Yeni Salma Barlinti. Hukum Perikatan Islam Di Indonesia. Jakarta: Kencana. 2005.

Djakfar, Muhammad. Etika Bisnis Dalam Perspektif Islam. Malang: UIN Malang Press. 2007.

Dyah Pekerti dan Eliada Herwiyanti, Jual Beli Online Dalam Perspektif Syariah Madzhab Asy-Syafi'i, Dikutip dari http://jp.feb.unsoed.ac.id, Diakses pada hari Selasa, tanggal 19 Februari 2019, Pukul 16.00 WIB.

Muhammad, Alimin. Etika \& Perlindungan Konsumen Dalam Ekonomi Islam. Yogyakarta: BPFE-Yogyakarta. 2004.

Mustafa, Imam. Fiqih Mu'amalah Kontemporer. Jakarta: PT, Raja Grafindo Persada, 2016. 
Norazlina Zainul., dkk. E-Commerce From An Islamic Perspective, Dikutip dari http:// sciencedirect.com, Diakses pada hari Senin, tanggal 28 Januari 2019, Pukul 19.00 WIB. 